\title{
PENGARUH MINAT DAN MOTIVASI TERHADAP AKTIVITAS DAN KESIAPAN BELAJAR FISIKA SISWA SMAN 1 SUKOMORO
}

\author{
Chindy Beauty S1), Singgih Bektiarso'), Sri Handono Budi Prastowo1) \\ pendidikan MIPA/ Pendidikan Fisika, Fakultas Keguruan dan Ilmu Pendidikan, Universitas Jember, Jember, \\ Jawa Timur, Indonesia \\ Corresponding author: Chindy Beauty S. \\ E-mail : cindybeauty73@gmail.com
}

Diterima 26 Maret 2021, Direvisi 19 April 2021, Disetujui 21 April 2021

\begin{abstract}
ABSTRAK
Prestasi siswa dalam pelajaran fisika rendah, hal ini disebabkan oleh rendahnya aktivitas dan kesiapan belajar. Aktivitas dan kesiapan belajar dipengaruhi oleh faktor internal dan eksternal seperti minat dan motivasi, penelitian ini bertujuan untuk mengetahui pengaruh minat belajar dan motivasi belajar terhadap aktivitas dan kesiapan belajar. Penelitian ini merupakan jenis penelitian kuantitatif, dengan desain penelitian kausal konfirmatori yang bertujuan untuk menguji hipotesis sebab akibat. Penelitian dilaksanakan di SMAN 1 Sukomoro dengan polulasi seluruh siswa kelas X, XI dan XII IPA sebanyak 327 siswa, dengan jumlah sampel 179 siswa. Pengambilan sampel menggunakan rumus slovin dengan dengan tingkat keakuratan $95 \%$ dan batas toleransi $5 \%$, instrumen yang digunakan berupa angket dengan skala likert. Analisis yang digunakan adalah analisis deskriptif dan analisis SEM. Hasil analisis deskiptif menunjukan bahwa minat belajar, motivasi belajar, aktivitas belajar dan kesiapan belajar siswa berada pada kategori sedang. Hasil analisis SEM menunjukkan minat belajar berpengaruh signifikan terhadap aktivitas belajar, minat belajar berpengaruh signifikan terhadap kesiapan belajar, motivasi belajar berpengaruh signifikan terhadap aktivitas belajar, motivasi belajar berpengaruh signifikan terhadap kesiapan belajar.
\end{abstract}

Kata kunci: aktivitas belajar; kesiapan belajar; minat belajar; motivasi belajar

\begin{abstract}
Student achievement in physics lessons is low, this is due to low activity and learning readiness. Activities and learning readiness are influenced by internal and external factors such as interest and motivation. This study aims to determine the effect of learning interest and learning motivation on activities and learning readiness. This research is a type of quantitative research, with a confirmatory causal research design that aims to test the causal hypothesis. The research was conducted at SMAN 1 Sukomoro with a total population of 327 students of class X, XI and XII IPA, with a total sample of 179 students. Sampling using the Slovin formula with an accuracy level of $95 \%$ and a tolerance limit of $5 \%$, the instrument used was a questionnaire with a Likert scale. The analysis used is descriptive analysis and SEM analysis. The results of descriptive analysis show that interest in learning, learning motivation, learning activities and student readiness are in the medium category. SEM analysis results show that learning interest has a significant effect on learning activities, learning interest has a significant effect on learning readiness, learning motivation has a significant effect on learning activities, learning motivation has a significant effect on learning readiness.
\end{abstract}

Keywords: learning activities; learning readiness; interest in learning; learning motivation

\section{PENDAHULUAN}

Pendidikan merupakan suatu sistem yang memiliki keteraturan yang didalamnya menjalankan misi yang luas yang berkaitan dengan mengembangkan fisik, keterampilan, kesehatan, pikiran, perasaan, sosial hingga keimanan seseorang (Suwartini, 2017). Pendidikan menjadi faktor yang penting bagi hidup manusia, kualitas pendidikan yang bagus mampu untuk menciptakan manusia yang cerdas dan dapat bersaing di era globaliasi.
Pendidikan berperan penting dalam pembentukan karakter, mental dan perkembangan ilmu seorang anak. Bekal ini lah yang akan digunakan untuk berinteraksi dengan lingkungannya baik secara individu ataupun kelompok (Pour et al., 2018).

Indonesia sedang menghadapi permasalahan pada taraf internasional dalam bidang pendidikan yaitu masih rendahnya prestasi siswa, pendapat tersebut diperkuat dengan hasil dari (PISA) Studi Programme For 
Internasional Student Assesment. Pada tahun 2018 kemampuan membaca negara indonesia dari 79 negara, berada pada peringkat 74 . Kategori kemampuan matematika negara indonesia dari 79 negara, berada pada peringkat 73. Sedangkan kategori kemampuan sains negara indonesia dari 79 negara, berada pada peringkat 73 (Hewi \& Shaleh, 2020).

Fisika merupakan suatu mata pelajaran yang masuk dalam kategori kelompok IPA (Ilmu Pengetahuan Alam), mata pelajaran fisika mempelajari tentang fenomena alam yang terjadi serta gejala yang turut menyertainya (Sujanem, 2012). Fisika merupakan ilmu yang memiliki sifat empiris, yang berarti semua hal yang dipelajari dalam fisika memiliki arti. Segala sesuatu yang ada dalam fisika didasarkan pada hasil dari proses (Sears \& Zemansky, 2002).

Fisika salah satu mata pelajaran yang sulit, sehingga prestasi siswa pada mata pelajaran fisika rendah. Menurut Bektiarso, (2015:21) secara umum dalam proses belajar guru masih menjadi pusat pembelajaran, dimana guru sebagai informan yang memberikan informasi dan pengetahuan melalui metode ceramah dan diskusi. Pernyataan tersebut didukung oleh hasil wawancara pada guru SMAN 1 Sukomoro yang menjelaskan bahwa metode ceramah, tanya jawab, diskusi dan penugasan merupakan metode yang sering digunakan dalam proses pembelajaran.

Rendahnya prestasi fisika siswa terjadi karena rendahnya aktivitas dan kesiapan belajar siswa. (Sabatina, 2014)menjelaskan bahwa aktivitas belajar berpengaruh terhadap prestasi belajar siswa, aktivitas belajar merupakan salah satu indkator yang dapat digunakan untuk mengukur tinggi rendahnya prestasi siswa. Pentingnya aktivitas belajar dalam proses pembelajaran, karena didalamnya terdapat interaksi belajar dan mengajar. Karena pada dasarnya belajar mempunyai prinsip berbuat, aktivitas belajar lebih ditekankan pada siswa. Karena dengan adanya aktivitas belajar pada siswa, maka proses pembelajaran akan bersifat aktif. Selain aktivitas belajar kesiapan juga memegang peran penting bagi prestasi belajar, siswa yang memiliki kesiapan belajar yang tinggi maka akan memaksimalkan prestasi belajarnya. (Harmini, 2017).

Aktivitas mempunyai arti "kegiatan atau keaktifan", sedangkan belajar merupakan serangkaian kegiatan yang dikerjakan oleh siswa dibantu dengan seseorang yang dilaksanakan dalam keadaan sadar. Sehingga mengakibatkan bertambah pengetahuan dan kemahiran yang sifatnya permanen (Nai, 2017). Aktivitas belajar dapat diukur dengan menggunakan indikator, berikut ini indikator aktivitas belajar : 1) aktivitas visual 2) aktivitas lisan 3) aktivitas mendengar 4) aktivitas menulis 5) aktivitas metrik (Usman, 2011).

Menurut Slameto (2010:59) kesiapan merupakan "preparedness to respond or react" yang berarti adalah persiapan yang dilakukan untuk merespon atau bereaksi. Sedangkan belajar merupakan serangkaian yang dilakukan oleh siswa dengan berbantuan seseorang yang dilaksanakan dalam keadaan sadar, sehingga mengakibatkan bertambahnya pengetahuan dan kemahiran yang sifatnya permanen (Nai, 2017). Kesiapan belajar dapat diukur dengan menggunakan indikator, berikut ini indikator kesiapan belajar : 1) kondisi fisik 2) kondisi mental 3) kondisi emosional 4) kebutuhan 5) pengetahuan.

Tinggi rendahnya aktivitas dan kesiapan belajar siswa tidak selalu karena cara mengajar guru, ada banyak faktor yang dapat mempengaruhinya. Secara garis besar faktor yang mempengaruhi aktivitas dan kesiapan belajar terbagi menjadi faktor internal dan eksernal. Faktor internal biasanya berasal dari diri siswa, sedangkan factor eksternal berasal dari luar diri siswa, faktor eksternal berasal dari lingkungan (Ahmadi \& Prasetyo, 2005). Faktor internal tidak kalah penting dibanding faktor eksternal, karena perubahan akan terjadi apabila didalam diri mucul suatu dorongan untuk berubah.

Minat merupakan salah satu faktor internal yang mempengaruhi aktivitas dan kesiapan belajar siswa, minat merupakan suatu perasaan senang dan ketertarikan terhadap suatu aktivitas atau objek. Seorang yang berminat akan dengan sendirinya memperhatikan aktivitas atau objek yang membuatnya tertarik, tanpa adanya paksaan dari luar (Slameto, 2010:180). Minat belajar siswa dapat diukur menggunakan indikator, berikut ini indikator minat belajar : 1) perasaan senang 2) ketertarikan 3) perhatian 4) keterlibatan (Safari, 2003:98).

Selain minat belajar motivasi juga merupakan faktor internal yang mempengaruhi aktivitas dan kesiapan belajar, motivasi merupakan suatu dorongan yang berasal dari internal dan eksternal siswa dalam belajar sehingga tingkah laku mengalami perubahan (Uno, 2013:23). Motivasi belajar siswa dapat diukur dengan menggunakan indikator, berikut ini indikator motivasi belajar : 1) hasrat dan keinginan berhasil 2) dorongan dan kebutuhan belajar 3) harapan dan cita cita masa depan 4) adanya penghargaan dalam belajar 5) adanya kegiatan yang menarik dalam belajar 6 ) adanya lingkungan belajar yang kondusif (Uno, 2013: 23). 
Penelitian yang dilakukan Ratnawati \& Marimin (2014) menunjukkan keaktifan belajar dipengaruhi oleh minat belajar. Penelitian yang dilakukan Setiawan et al (2019) menjelaskan bahwa secara tidak langsung ada pengaruh positif minat belajar terhadap aktivitas belajar. Penelitian yang dilakukan oleh Riyanti \& Rustiana (2018) menghasilkan adanya pengaruh signifikan positif motivasi terhadap keaktifan belajar. Penelitian yang dilakukan Ma'shumah \& Muhsin (2019) menghasilkan adanya pengaruh secara parsial motivasi belajar berpengaruh secara pasial motivasi terhadap kesiapan belajar.

Berdasarkan uraian tersebut, maka dilakukan penelitian yang dengan tujuan untuk membuktikan teori pengaruh minat dan motivasi terhadap aktivitas dan kesiapan belajar fisika.

\section{METODE PENELITIAN}

Jenis penelitian yang digunakan, adalah penelitian kuantitatif, dengan menggunakan data angka untuk dilakukan analisis sehingga didapatkan pengetahuan. Fokus penelitian jenis ini pada aspek pengukuran secara objektif pada fenomena dengan dibantu alat ukuryang berupa kuisioner (Kasiram, 2008). Desain penelitian kausal konfirmatori, desain ini digunakan untuk mengkonfimasi atau menganalisis ada tidaknya suatu hubungan antar variabel dimana setiap variabel memiliki indicator. Penelitian kausal bertujuan untuk menguji hipotesis sebab akibat, artinya terdapat variabel mempengaruhi dan variabel yang menjadi akibat dipengaruhi.

Pengumpulan data pada penelitian, menggunakan teknik : 1) wawancara digunakan untuk informasi pendukung 2) angket merupakan teknik pengumpulan data yang berupa pernyataan tertulis yang dibagikan kepada responden dengan tujuan mendapatkan informasi 3) dokumentasi digunakan untuk mendokumentasikan kegiatan penelitian, jumlah kelas dan jumlah siswa pada masing masing kelas. Penentuan tempat penelitian menggunakan metode purposive sampling yang memiliki arti penentuan tempat penelitian didasarkan tujuan dan pertimbangan tertentu (Arikunto, 2014), peneliti memilih metode ini karena ketersediaan sekolah, tenaga dan waktu yang terbatas dan juga dana dari peneliti sehingga tidak memungkinkan mengambil sampel yang jauh. Populasi yang digunakan adalah semua kelas X, XI dan XII jurusan IPA sebanyak 327 siswa, rumus slovin digunakan untuk pengambilan sampel.

$$
n=\frac{N}{N d^{2}+1}
$$

Keterangan :

$\mathrm{n}$ : jumlah sampel

$\mathrm{N}$ : populasi total

$d^{2}$ : error tolerance

dengan tingkat keakuratan 95\% dengan batas toleransi $5 \%$

Berikut ini alur penelitian yang dilakukan, yaitu persiapan, observasi, pembuatan instrumen, uji validitas dan reliabilitas intrumen, penyebaran instrumen, pengumpulan data, analisis dan kesimpulan

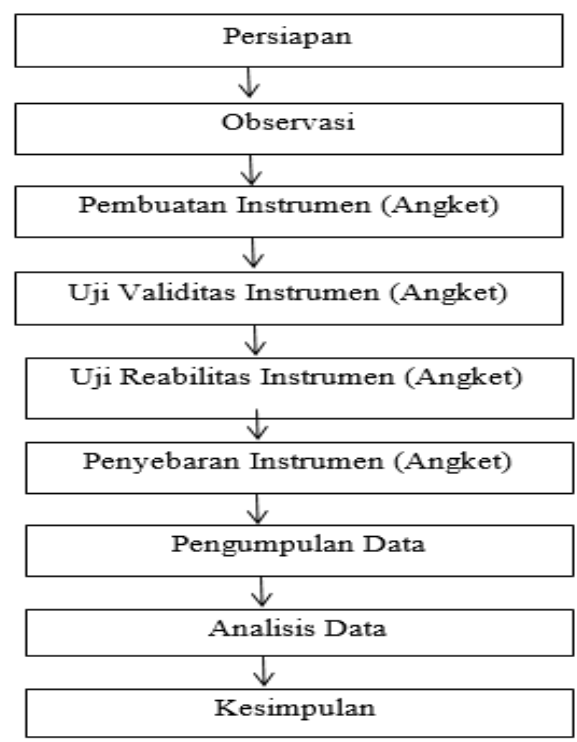

Gambar 1. Alur penelitian

\section{Persiapan}

Persiapan yang dilakukan untuk mengurus surat surat yang dibutuhkan untuk penelitian kesekolah, selain itu mencari mencari dasar teori yang dibutuhkan untuk memperkuat penelitian ini

\section{Observasi}

Observasi dilakukan untuk melihat kondisi sekolah, sebagai informasi yang digunakan untuk melakukan penelitian

\section{Pembuatan instrument}

Terdapat 4 angket yaitu untuk angket minat belajar, motivasi belajar, aktivitas belajar dan kesiapan belajar. Angket yang dipakai merupakan jenis angket tertutup, yang artinya hanya bisa memilih jawaban yang disediakan peneliti dengan menggunakan skala likert 5 tingkat. 
Tabel 1. Kriteria angket skala likert

\begin{tabular}{llll}
\hline No & Pilihan jawaban & Positif & Negatif \\
\hline 1 & Sangat Setuju (SS) & 5 & 1 \\
\hline 2 & Setuju (S) & 4 & 2 \\
\hline 3 & Ragu Ragu (RR) & 3 & 3 \\
\hline 4 & Tidak Setuju (TS) & 2 & 4 \\
\hline 5 & $\begin{array}{l}\text { Sangat Tidak Setuju } \\
\text { (STS) }\end{array}$ & 1 & 5 \\
\hline
\end{tabular}

\section{Uji validitas instrumen}

Uji validitas instrumen bertujuan untuk mengetahui apakah pernyataan setiap butir intrumen valid atau tidak. Uji validitas dilakukan dengan membandingkan rhitung dangan rtabel, jika rhitung > rtabel maka valid. Pada penelitian ini menggunakan 30 responden dengan taraf signifikansinya sebesar $5 \%$, sehingga didapatkan rtabelnya 0,361 . Pada minat belajar semua pernyataan valid karena rhitung $>$ rtabel. Pada motivasi belajar terdapat 4 pernyataan yang tidak valid dimana rtabelnya 0,077 , 0,351, 0,272, 0,209. Pada aktivitas belajar terdapat 2 pernyataan yang tidak valid dimana rtabelnya $0,316,0,235$. Pada kesiapan belajar terdapat 3 pernyataan yang tidak valid dimana rtabelnya $0,305,0,14$, 0,020 . Pernyataan yang tidak valid harus dibuang.

\section{Uji reliabilitas instrumen}

Uji reliabilitas bertujuan untuk mengetahui reliabel atau tidaknya sebuah instrumen, instrumen yang reliabel menghasilkan data yang sama walaupun dipakai berkali kali dengan objek yang sama. Pada minat belajar nilai cronbach's alpha sebesar 0,838 , pada motivasi belajar nilai cronbach's alpha sebesar 0,879, pada aktivitas belajar nilai cronbach's alpha sebesar 0,849 , pada kesiapan belajar nilai cronbach's alpha sebesar 0,881. Instrumen dikatakan reliabel apabila nilai cronbach's alpha > 0,6, sehingga semua instrumen dikatakan reliabel

\section{Penyebaran instrumen}

Angket yang lolos uji validitas dan reliabilitas kemudian disebar luaskan pada sampel penelitian yang telah ditentukan. Penyebaran angket dilakukan secara langsung pada 179 sampel penelitian yang terdiri dari kelas X, XI dan XII IPA dengan memanfaatkan jam pelajaran fisika, waktu yang dibutuhkan untuk penyebaan angket ini sekitar 1 minggu

\section{Pengumpulan data}

Angket yang sudah disebar selanjutnya di kumpulkan untuk kemudian dilakukan perekapan pada masing masing variabel

\section{Analisis data}

Analisis data yang digunakan yaitu analisis desktiptif dan analisis SEM (Structural Equation Modeling). Analisis desktiptif Analisis deskriptif dipakai untuk menggambarkan kondisi dan karakteristik jawaban pertanyaan yang ada pada angket yang telah dijawab serta pengelompokkan dengan 5 kategori.

Tabel 2. Kategori pengelompokan

\begin{tabular}{ll}
\hline Interval & Kriteria \\
\hline$X \leq M-1,5 S D$ & $\begin{array}{l}\text { Sangat } \\
\text { rendah }\end{array}$ \\
\hline$M-1,5 S D<X \leq M-0,5 S D$ & Rendah \\
\hline$M-0,5 S D<X \leq M+0,5 S D$ & Sedang \\
\hline$M+0,5 S D<X \leq M+1,5 S D$ & Tinggi \\
\hline$X>M+1,5 S D$ & Sangat tinggi \\
\hline$X \leq M-1,5 S D$ & $\begin{array}{l}\text { Sangat } \\
\text { rendah }\end{array}$ \\
\hline & (Azwar 2012)
\end{tabular}

(Azwar, 2012)

Analisis SEM digunakan untuk membuktikan teori hubungan antara variabel $X$ terhadap variabel Y. Pada analisis SEM terdapat 7 tahapan yaitu :

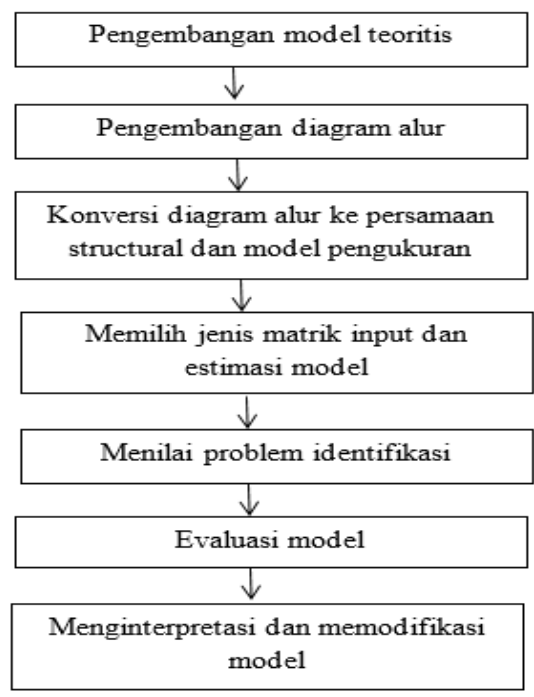

(Ferdinan, 2014:45-64)

Gambar 2. Langkah langkah analisis SEM

\section{Kesimpulan}

Analisis yang telah selesai dilakukan, kemudian ditarik kesimpulan. Kesimpulan ini yang akan menjawab rumusan masalah, apakah hipotesisinya diterima atau ditolak 


\section{HASIL}

telah dilakukan

Tabel 3. Analisis deskriptif

\begin{tabular}{lrrr}
\hline & N & Mean & $\begin{array}{c}\text { Std. } \\
\text { Deviation }\end{array}$ \\
\hline Minat_Belajar & 179 & 56,6816 & 7,30663 \\
\hline Motivasi_Belajar & 179 & 70,7039 & 7,18195 \\
\hline Aktivitas_Belajar & 179 & 63,3520 & 7,56130 \\
\hline Kesiapan_Belajar & 179 & 58,4749 & 7,09591 \\
\hline Valid N (listwise) & 179 & & \\
\hline
\end{tabular}

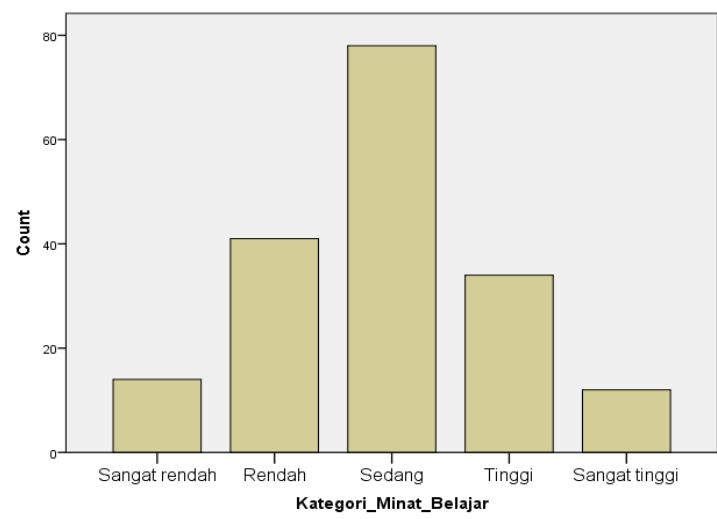

Gambar 3. Grafik minat belajar

Pada gambar 3 dapat diketahui bahwa minat belajar fisika siswa SMAN 1 Sukomoro dari 179 siswa yang dijadikan sampel penelitian, 14 $(7,8 \%)$ siswa masuk kategori sangat rendah, 41 $(22,9 \%)$ siswa masuk kategori rendah, 78 $(43,6 \%)$ siswa masuk kategori sedang, 34 $(19,0 \%)$ siswa masuk kategori tinggi, $12(6,7 \%)$ siswa masuk kategori sangat tinggi

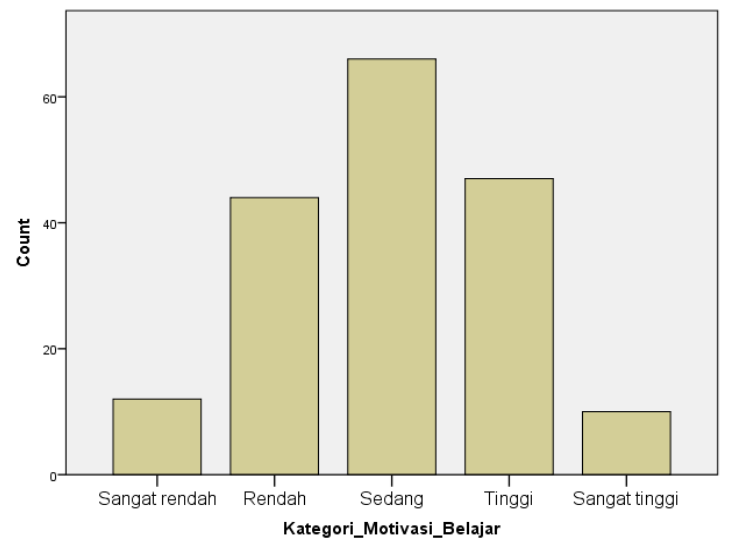

Gambar 4. Grafik motivasi belajar

Pada gambar 4 dapat diketahui bahwa motivasi belajar fisika siswa SMAN 1 Sukomoro dari 179 peserta yang dijadikan sampel penelitian, 12 $(6,7 \%)$ siswa masuk kategori sangat rendah, $44(24,6 \%)$ siswa masuk kategori rendah, 66
$(36,9 \%)$ siswa masuk kategori sedang, 47 $(26,3 \%)$ siswa masuk kategori tinggi, 10 (5,6\%) siswa masuk kategori sangat tinggi

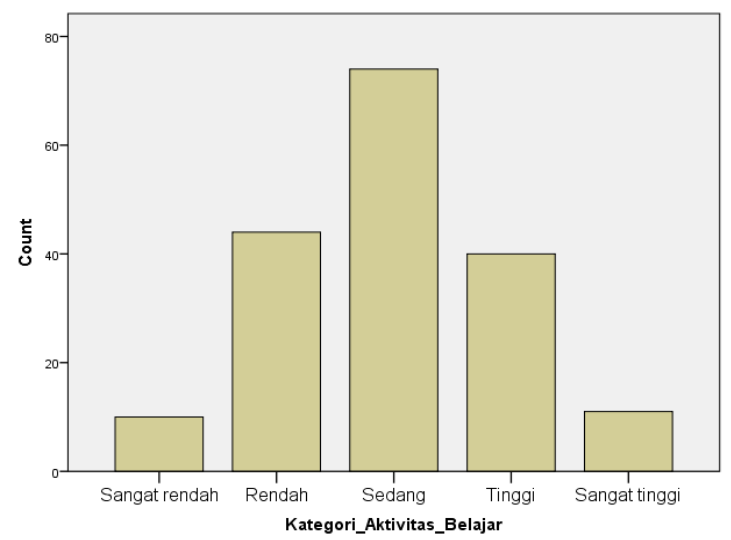

Gambar 5. Grafik aktivitas belajar

Pada gambar 5 dapat diketahui bahwa aktivitas belajar fisika siswa SMAN 1 Sukomoro dari 179 siswa yang dijadikan sampel penelitian, 10 $(5,6 \%)$ siswa masuk kategori sangat tendah, 44 $(24,6 \%)$ siswa masuk kategori rendah, 74 $(41,3 \%)$ siswa masuk kategori sedang, 40 $(22,3 \%)$ siswa masuk kategori tinggi, $11(6,1 \%)$ siswa masuk kategori sangat tinggi

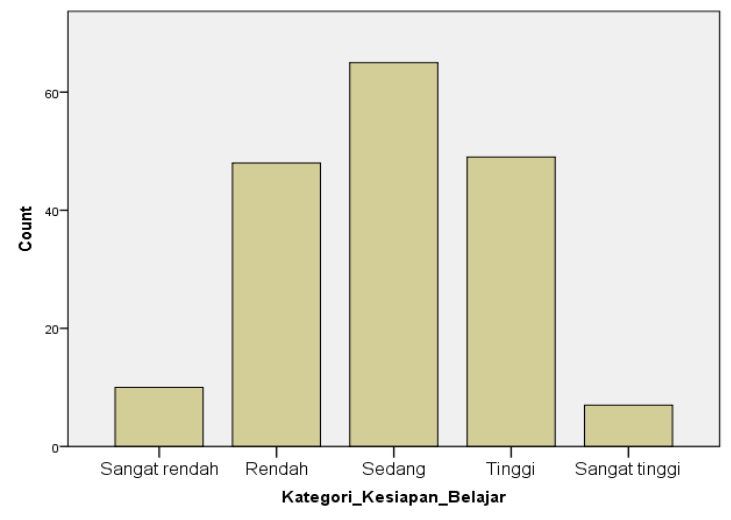

Gambar 6. Grafik kesiapan belajar

Pada gambar 6 dapat diketahui bahwa kesiapan belajar fisika siswa SMAN 1 Sukomoro dari 179 siswa yang dijadikan sampel penelitian, 10 (5,6\%) siswa masuk kategori sangat rendah, $48(26,8 \%)$ siswa masuk kategori rendah, $65(36,3 \%)$ siswa masuk kategori sedang, 49 (27,4\%) siswa masuk kategori tinggi, 7 (3,9\%) siswa masuk kategori sangat tinggi

Analisi SEM dilakukan untuk menguji hipotesis penelitian, dalam analisis SEM terdapat 7 tahapan/ langkah 


\section{1) Pengembangan model teoritis}

Model teoritis dihasilkan dari tinjuan pustaka atau teori yang sudah ada, serta memliki hubungan yang kuat. Selain dari teori, sangat penting untuk mencari penelitian yang mendukung. Karena jika dasar teori tidak kuat/ lemah analisis SEM tidak dapat dilakukan, jika peneliti memiliki dasar teori yang kuat maka dapat melangkah ke tahap selanjutnya.Jjika dirasa dasar teori belum cukup kuat maka disarankan untuk memperkuat dasar teori terlebih dahulu, baik pada buku ataupun penelitian yang mendukung lainnya

\section{2) Pengembangan diagram alur}

Diagram alur digunakan untuk memudahkan peneliti dan pembaca untuk mengetahui hubungan antar variabel $X$ terhadap $Y$, hubungan yang dimaksud adalah hubungan sebab akibat. Variabel $X$ merupakan variabel bebas, yang menyebabkan terjadinya perubahan pada variable $Y$. peneliti memfokuskan pada hubungan minat motivasi terhadap aktivitas dan kesiapan belajar

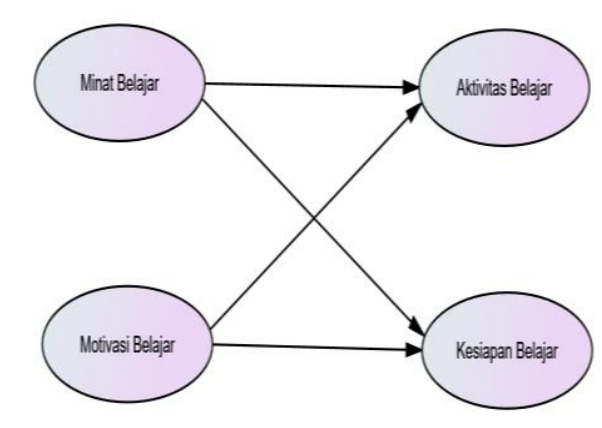

Gambar 7. Analisis jalur antar variabel

\section{3) Konversi diagram alur kedalam persamaan struktrual}

Setelah diagram alur terbentuk, kemudian memasukkan pada persamaan structural. Dimana pada masing masing variabel memiliki indikator indikator yang dijadikan sebagai tolak ukur yang mewakili masing masing variabel

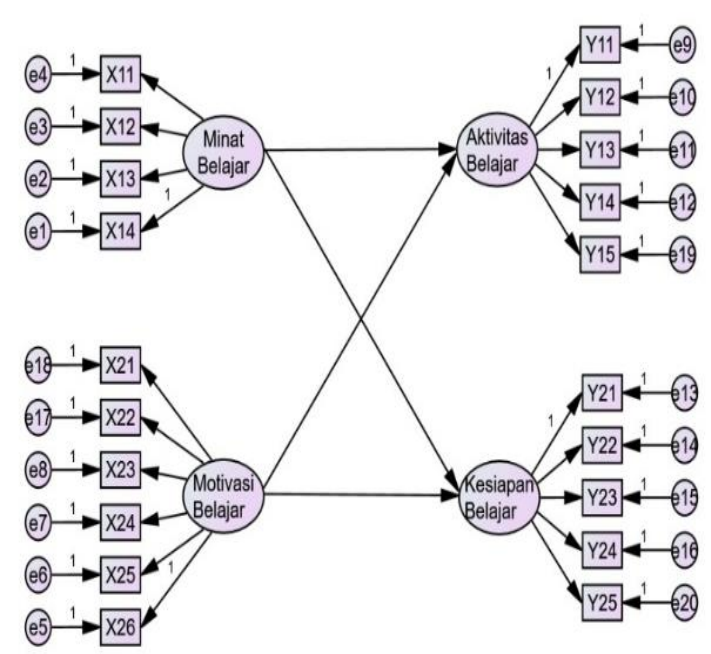

Gambar 8. Diagram analisis SEM

4) Memilih jenis matrik input dan estimasi

Matrik kovarian yang akan digunakan pada analisis ini, peneliti menggunakan matrik kovarian ketika menguji teori untuk dilakukan validasi terhadap hubungan sebab-akibat karena dianggap lebih memenuhi asumsi asumsi metodologi. Karena sampel yang digunakan antara 100 - 200 sampel maka teknik estimasi yang digunakan adalah estimasi maximum likehood

\section{5) Menilai problem identifikasi}

Problem identifikasi biasanya terjadi apabila model yang dikembangkan memiliki estimasi yang tidak baik, biasanya program akan mengirim pesen kemonitor apabila estimasi tidak dapat dilakukan serta kemungkinan penyebabnya. Peneliti bisa melakukan dengan memberi indikator lebih banyak atau mengurangi untuk mengatasi problem identifikasi

\section{6) Evaluasi model SEM}

- Asumsi normalitas : syarat yang harus dipenuhi sebelum menggunakan teknik estimasi likehood adalah terpenuhinya uji normalitas, untuk mengetahui data yang didapatkan berasal dari populasi yang terdistribusi normal atau tidak. Data dikatakan normal bila nilai c.r kurtosis $<3$. Pada uji normaliitas nilai c.r kurtosis yang diperoleh adalah 2,663, maka data dikatakan normal

- Uji linieritas : pada uji linieritas menggunakan SPSS, uji linieritas digunakan untuk mengetahui apakah hubungan indikator dengan variabel dan variabel dengan variabel linier atau tidak. Data yang 
dihasilkan semuanya linier, dapat dilihat dari deviation of linearity dengan nilai sig $>0,05$

- Multikolinierias : multikolinieritas mampu terdeteksi dengan melihat nilai determinan matrik kovarian, nilai determinan yang kecil berarti menandakan tidak ada multikolinieritas. Berdasarkan matrik yang dihasilkan, tidak ada multikolinieritas

- Uji validitas dan reliabilitas : untuk uji validitas indikator pada analisis SEM di Standardized Regression Weights pada nilai estimasinya/ loading factornya $>0,5$. Jika nilai loading factornya $<0,5$ maka indikator tersebut harus dihapus, apabila tidak dihapus model yang dihasilkan tidak bagus. Setelah uji validitas ternyata pada variabel motivasi belajar X4 dikatakan tidak valid maka harus dibuang. Selanjutnya uji reliabilitas, dikatakan reliabel apabila nilai construct reliability $>0,5$. Nilai construct reliabilitty didapatkan dari kuadrat nilai total standart loading dibagi kuadrat nilai total standart loading ditambah jumlah eror. Setelah uji reliabilitas dapat diketahui

bahwa semua indikator pada variabel dikatakan reliabel, untuk variabel minat belajar nilai construct reliability 0,717 , variabel motivasi belajar nilai construct reliability 0,761 , variabel aktivitas belajar nilai construct reliability 0,761 , variabel kesiapan belajar 0,640

- $\quad$ Berikut ini gambar analisis SEM setelah mengeluarkan indikator $\mathrm{X} 4$ pada motivasi belajar, karena diketahui indikator X4 tidak valid. Karena model yang dihasilkan kurang baik maka diperlukan untuk memodifikasi indeks, supaya model yang dihasilkan memenuhi ktriteria. Berikut ini hasil model setelah menghapus $\mathrm{X} 4$ dan memodifikasi indeks

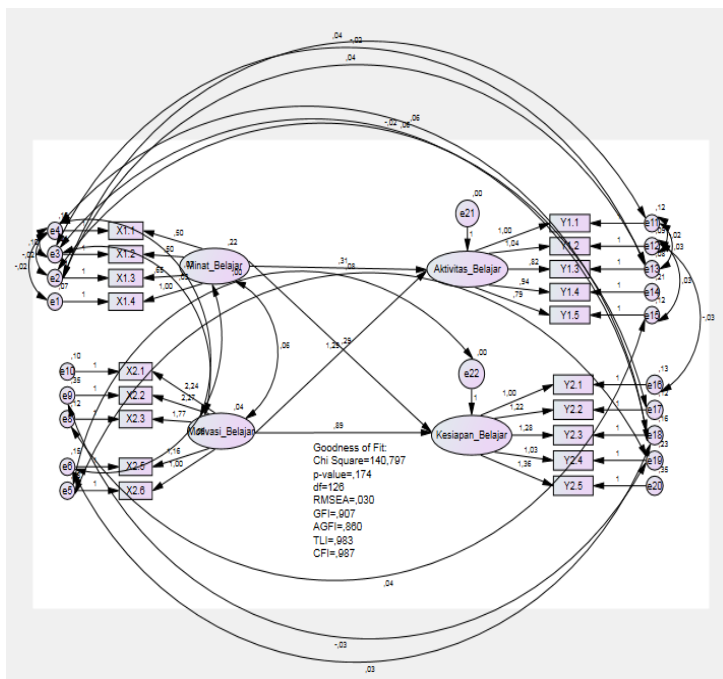

Gambar 9. Diagram analisis SEM setelah memodifikasi indeks
- Evaluasi model : evaluasi model bertujuan untuk menguji apakah model sudah cocok atau belum, pada analisis SEM dihasilkan parameter kemudian dibandingkan dengan cut-of value dari goones of fit. Berikut ini adalah hasil dari evaluasi model yang telah dilakukan

Tabel 3. Hasil evaluasi model

\begin{tabular}{cccc}
\hline $\begin{array}{c}\text { Goodness } \\
\text { Of Fit } \\
\text { Indeces }\end{array}$ & $\begin{array}{c}\text { Cut- } \\
\text { Off } \\
\text { Value }\end{array}$ & Hasil & Keterangan \\
\hline$\chi^{2}($ Chi & $\leq \chi^{2}{ }_{0,05}$ & 140,7 & Baik \\
Square) & & 97 & \\
\hline Probabilitas & $\geq 0,05$ & 0,174 & Baik \\
\hline RMSEA & $\leq 0,08$ & 0,030 & Baik \\
\hline GFI & $\geq 0,90$ & 0,907 & Baik \\
\hline AGFI & $\geq 0,90$ & 0,860 & Kurang baik \\
\hline TLI & $\geq 0,95$ & 0,983 & Baik \\
\hline CFI & $\geq 0,95$ & 0,987 & Baik \\
\hline
\end{tabular}

Pada tabel 3 dapat dilihat dari 7 kriteria terdapat 6 kriteria dengan keterangan baik sedangkan terdapat 1 kriteria yang kurang baik. Namun hal ini sudah menunjukkan bahwa model secara keseluruhan dapat diterima dan cocok

- Uji hipotesis : uji hipotesis bisa dilihat dari hasil uji signifikansi parameter dari analisis SEM, berikut ini merupakan hasil dari parameter yang dihasilkan pada analisis SEM yang nantinya akan digunakan untuk menolak atau menerima hipotesis penelitian

Tabel 4. Uji hipotesis analisis SEM

\begin{tabular}{lllll}
\hline Hubungan & $\begin{array}{l}\text { Estim } \\
\text { ate }\end{array}$ & S.E. & C.R. & P \\
\hline Aktivitas & 0,306 & 0,082 & 3,75 & *** \\
$\leftarrow$ Minat & & & 0 & \\
\hline Kesiapan & 0,291 & 0,080 & 3,63 & *** \\
$\leftarrow$ Minat & & & 6 & \\
\hline $\begin{array}{l}\text { Aktivitas } \\
\leftarrow \text { Motivasi }\end{array}$ & 1,288 & 0,314 & $\begin{array}{l}4,10 \\
\text { *** }\end{array}$ & \\
\hline Kesiapan & 0,893 & 0,244 & 3,66 & *** \\
$\leftarrow$ Motivasi & & & 1 & \\
\hline
\end{tabular}

Untuk menguji hipotesis pada analisis SEM dapat dilihat dari nilai c.r dan probabilitasnya $(P)$, hipotesis diterima apabila nilai c.r $>1,96$ dan nilai probabilitasnya $(P)<0,05 . P^{* * *}$ menunjukkan adanya pengaruh yang signifikan karena sama dengan 0,000

Hipotesis 1

$\mathrm{H}_{0}$ : tidak ada pengaruh minat belajar terhadap aktivitas belajar fisika siswa SMAN 1 Sukomoro $\mathrm{H}_{1}$ : ada pengaruh minat belajar terhadap aktivitas belajar fisika siswa SMAN 1 Sukomoro 
Pada tabel diatas didapatkan nilai C.R pengaruh hubungan minat belajar terhadap aktivitas belajar sebesar 3,70 >1,96 dengan probabilitas ${ }^{* *}$. Maka diperoleh keputusan $\mathrm{H}_{0}$ ditolak

\section{Hipotesis 2}

$\mathrm{H}_{0}$ : tidak ada pengaruh minat belajar terhadap kesiapan belajar fisika siswa SMAN 1 Sukomoro

$\mathrm{H}_{1}$ : ada pengaruh minat belajar terhadap kesiapan belajar fisika siswa SMAN 1 Sukomoro

Pada tabel diatas didapatkan nilai C.R pengaruh hubungan minat belajar terhadap kesiapan belajar sebesar 3,636 > 1,96 dengan probabilitas ${ }^{* * *}$. Maka diperoleh keputusan $\mathrm{H}_{0}$ ditolak

\section{Hipotesis 3}

$\mathrm{H}_{0}$ : tidak ada pengaruh motivasi belajar terhadap aktivitas belajar fisika siswa SMAN 1 Sukomoro

$\mathrm{H}_{1}$ : ada pengaruh motivasi belajar terhadap aktivitas belajar fisika siswa SMAN 1 Sukomoro Pada tabel diatas didapatkan nilai C.R pengaruh hubungan motivasi belajar terhadap aktivitas belajar sebesar 4,108 > 1,96 dengan probabilitas ${ }^{* * *}$. Maka diperoleh keputusan $\mathrm{H}_{0}$ ditolak

\section{Hipotesis 4}

$\mathrm{H}_{0}$ : tidak ada pengaruh motivasi belajar terhadap kesiapan belajar fisika siswa SMAN 1 Sukomoro

$\mathrm{H}_{1}$ : ada pengaruh motivasi belajar terhadap kesiapan belajar fisika siswa SMAN 1 Sukomoro

Pada tabel diatas didapatkan nilai C.R pengaruh hubungan minat belajar terhadap aktivitas belajar sebesar 3,661 > 1,96 dengan probabilitas ${ }^{* \star *}$. Maka diperoleh keputusan $\mathrm{H}_{0}$ ditolak

\section{PEMBAHASAN}

Penelitian ini dilaksanakan secara langsung di SMA Negaeri 1 Sukomoro, tepatnya pada tanggal 15- 28 November 2020. Sampel dari penelitian ini adalah kelas X, XI,XII IPA, dengan kelas $X$ sebanyak 64 , kelas $X I$ sebanyak 55 dan kelas XII sebanyak 60 dengan total keseluruhan adalah 179 siswa. Penelitian ini dilaksanakan secara langsung, alasan peneliti melakukan penelitian langsung adalah karena jumlah pernyataan angket yang banyak. Sehingga peneliti kawatir apabila dilakukan secara online banyak yang tidak mengisi sehingga sampel tidak memenuhi, pertimbangan lainnya adalah karena peneliti dapat mengawasi siswa dalam mengisi angket.
Penelitian ini terdapat 4 variabel yaitu minat belajar, motivasi belajar, aktivitas belajar dan kesiapan belajar. Sehingga angket yang disedikan sebanyak 4 buah untuk mewakili masing masing, dengan setiap indikator diwakili 4 butir pernyataan. Variabel minat belajar terdapat 4 indikator dengan total pernyataan sebanyak 20 butir, variabel motivasi belajar terdapat 6 indikator dengan total pernyataan sebanyak 24 butir, variabel aktivitas belajar terdapat 5 indikator dengan total pernyataan sebanyak 20 butir dan variabel kesiapan belajar terdapat 5 indikator dengan total pernyataan 20 butir.

Angket yang sudah jadi kemudian disebarkan pada 30 siswa, untuk selanjutnya diuji validitas dan reliabilitas pada msing masing pernyataan. Uji validitas instrumen dilakukan untuk mengetahui apakah instrumen layak atau tidak digunakan. Pada angket minat belajar terdapat 4 indikator dengan masing masing indikator terdiri dari 4 pernyataan, dari 16 pernytaan semua dikatakan valid dan juga reliabel. Pada angket motivasi belajar terdapat 6 indikator dengan masing masing masing indikator terdapat 4 pernyataan yang mewakili, dari 24 pernyataan 4 dikatakan tidak valid dan 20 dikatakan valid uji reliablitias menunjuukan bahwa instrumen dikatakan reliabel. Pada angket aktivitas belajar terdapat 5 indikator dengan masing masing masing indikator terdapat 4 pernyataan yang mewakili, dari 20 pernyataan 2 dikatakan tidak valid dan 18 dikatakan valid uji reliablitias menunjuukan bahwa instrumen dikatakan reliabel. Pada angket kesiapan belajar terdapat 5 indikator dengan masing masing masing indikator terdapat 4 pernyataan yang mewakili, dari 20 pernyataan 3 dikatakan tidak valid dan 17 dikatakan valid uji reliablitias menunjuukan bahwa instrumen dikatakan reliabel.

Berdasarkan analisis SEM yang telah dilakukan, didapatkan hasil bahwa minat belajar berpengaruh signifikan terhadap aktivitas belajar, ditinjau dari hasil uji hipotesisis analisis SEM dimana nilai c.r yang didapatkan $3,750>1,967$ dengan nilai probabilitas ${ }^{* \star *}$ yang artinya memiliki pengaruh yang signifikan. Sehingga apabila minat belajar siswa tinggi maka dapat dipastikan bahwa aktivitas belajarnya juga akan tinggi (Besare, 2020). Semakin tinggi minat belajar siswa maka akan berpengaruh semakin besar terhadap aktivitas belajar, siswa yang berminat pada saat pembelajaran lebih aktif dan bersemangat sehingga tujuan pembelajaran dapat dicapai secara maksimal (Rozai, 2017). Minat belajar berperan penting dalam belajar, minat yang tinggi membuat siswa lebih aktif dalam menemukan pengetuhannya sendiri, 
pengetahuan yang dihasilkan secara mandiri akan lebih bertahan lama (Dalyonoo, 2009).

Berdasarkan analisis SEM yang telah dilakukan, didapatkan hasil bahwa minat belajar berpengaruh signifikan terhadap kesiapan belajar, ditinjau dari hasil uji hipotesisi analisis SEM dimana nilai c.r yang didapatkan 3,636 > 1,967 dengan nilai probabilitas *** yang artinya memiliki pengaruh yang signifikan. Minat belajar berpengaruh terhadap kesiapan belajar, siswa yang berminat akan melakukan kesiapan yang lebih dibandingkan siswa yang tidak berminat (Setiawan et al., 2019), artinya terdapat perbedaan kesiapan antara siswa yang memiliki minat tinggi dengan siswa yang memiliki minat yang rendah (Nasution et al., 2020). Siswa yang memiliki minat tinggi akan mempertahankan dan mengembangkan kemampuan dirinya sehingga kesiapan belajarnya akan meningkat (Alawiyah, 2013).

Berdasarkan analisis SEM yang telah dilakukan, didapatkan hasil bahwa motivasi belajar berpengaruh signifikan terhadap aktivitas belajar, ditinjau dari hasil uji hipotesisi analisis SEM dimana nilai c.r yang didapatkan $4,108>1,967$ dengan nilai probabilitas *** yang artinya memiliki pengaruh yang signifikan. Motivasi belajar perpengaruh signifikan terhadap aktivitas belajar siswa (Siswanto. 2020), apabila motivasi belajar siswa tinggi maka aktivitas belajar siswa juga akan tinggi karena motivasi memiliki peran yang sangat penting bagi aktiviitas belajar (Junianti, 2019). Pemberian motivasi oleh guru berupa semangat, apresiasi dan dorongan membuat siswa lebih percaya pada kemampuannya sehingga siswa menjadi lebih aktif ddalam proses pembelajaran (Sagala, 2020). Aktivitas yang tinggi akan berperngaruh pada prestasi belajar yang dihasilkan akan lebih maksimal (Gunawan, 2018).

Berdasarkan analisis SEM yang telah dilakukan, didapatkan hasil bahwa motivasi belajar berpengaruh signifikan terhadap kesiapan belajar, ditinjau dari hasil uji hipotesisi analisis SEM dimana nilai c.r yang didapatkan $3,661>1,967$ dengan nilai probabilitas *** yang artinya memiliki pengaruh yang signifikan. Motivasi belajar berpengaruh terhadap kesiapan belajar siswa (Yanida \& Pramusinto, 2014), siswa akan berhasil mencapai tujuannya apabila didalam dirinya muncul dorongan yang mempengaruhinya untuk melakukan kesiapan yang lebih (Ma'shumah \& Muhsin, 2019). Motivasi belajar dapat membuat siswa lebih semangat dalam mengikuti proses pembelajaran, karena sudah memiliki bekal yang cukup untuk mengikuti proses pembelajaran (Kusuma \& Muhsin, 2013)
Aktivitas belajar sangat penting dalam proses pembelajaran, aktivitas belajar digunakan sebagai tolak ukur berhasil tidaknya suatu pembelajaran. Guru dalam merancang kegiatan belajar haruslah berorientasi pada kegiatan peserta siswa, artinya guru tidak hanya memindahkan ilmu kepada pesrta didik melainkan harus mencipptakan suatu kondisi yang mengharuskan siswa bertindak aktif untuk menemukan pengetahunnya sendiri (Meilon et al., 2019). Selain aktivitas belajar kesiapan belajar juga sangat penting pada proses pembelajaran, kesiapan merupakan suatu landasan yang sangat penting dalam proses pembelajaran, karena jika tidak ada kesiapan dalam diri siswa maka dapat dipastikan hasil yang didapatkan tidak akan maksimal (Jumasrin, 2019).

Pada hasil analisis deskriptif yang telah dilakukan aktivitas dan kesiapan belajar siswa berada pada kategori sedang, artinya perlu adanya suatu peningkatan agar aktivitas dan kesiapan siswa dapat meningkat. Salah satu caranya dengan meningkatkan minat dan motivasi belajar pesertd didik, dengan meningkatnya minat dan motivasi belajar siswa diharapkan mampu untuk meningkatkan aktivitas dan kesiapan belajar siswa.

Berikut ini yang dapat dilakukan guru untuk meningkatka minat belajar siswa : 1) guru hendaknya membuat proses belajar lebih variatif dan inovatif, sehingga meningkatkan minat dan semangat siswa 2) guru hendaknya mengaitkan materi pembelajaran pada kehidupan sehari hari, sehingga membuat siswa lebih memahami materi yang disampaikan 3) guru hendaknya melibatkan langsung siswa secara aktif dalam proses pembelajaran (Tafonao, 2018). Selain itu dengan menerapkan metode pembelajaran yang melatih siswa untuk aktif dalam proses pembelajaran, penggunaan metode pembelajaran yang tidak tepat mengakibatkan siswa tidak berminat sehingga tujuan pembelajaran tidak tercapai secara maksimal (Silviani et al., 2017)

Berikut ini yang dapat dilkukan meningkatkan motivasi belajar siswa : 1) guru dapat memberikan arahan dan pemahaman tentang pentingnya belajar, sehingga dapat memotivasi siswa 2) guru dapat membuat pembelajaran lebih inofatif 3) orang tua memiliki peran yang besar dalam mendidik anaknya dirumah serta semenuhi segala kebutuhan belajarnya 4) sekolah dapat mengadakan program parenting sebulan sekali sehingga terjadi kesinambungan sekolah dengan orang tua (Gunawan, 2018)

\section{SIMPULAN DAN SARAN}


Berdasarkan pada hasil penelitian yang telah dilakukan dapat ditarik kesimpulan bahwa minat belajar berpengaruh terhadap aktivitas belajar, minat belajar berpengaruh terhadap kesiapan belajar, motivasi belajar berpengaruh terhadap aktivitas belajar dan motivasi belajar berpengaruh terhadap kesiapan belajar. Saran yang bisa peneliti berikan adalah bisa dilakukan penelitian terkait aktivitas dan kesiapan belajar dengan mengaitkan factor lainnya misalkan faktor eksternal seperti lingkungan sekolah, keluarga dan masyarakat untuk dapat mengetahui adakah pengaruh faktor tersebut terhadap aktivitas dan kesiapan belajar

\section{UCAPAN TERIMAKASIH}

Ucapan terima kasih disampaikan pada semua pihak yang turut terlibat dalam terlaksananya penelitian

\section{DAFTAR RUJUKAN}

Ahmadi, A., \& Prasetyo, J. T. (2005). Strategi Belajar Mengajar. Bandung: Pustaka Setia.

Alawiyah, L. (2013). Pengaruh Minat Belajar Terhadap Kesiapan Belajar Matematika Kelas VIII Di Mts Negeri Gegesik. Skripsi.

Arikunto, S. (2014). Prosedur Penelitian Suatu Pendekatan Praktik. Jakarta: Rineka Cipta.

Azwar, S. (2012). Penyusunan Skala Psikologi Edisi 2. Yogyakarta : Pustaka Pelajar.

Bektiarso, S. (2015). Stategi Pembelajaran. Yogyakarta: LaksBag PRESSindo.

Besare, S. (2020). Hubungan Minat dengan Aktivitas Belajar Siswa. JINOTEP (Jurnal Inovasi Dan Teknologi Pembelajaran): Kajian Dan Riset Dalam Teknologi Pembelajaran, 7(1), 18-25. https://doi.org/10.17977/um031v7i12020p 018

Dalyonoo, M. (2009). Psikologi Pendidikan. Jakarta : Rineka Cipta.

Ferdinan, A. (2014). Structural Equation Modeling (5th ed.). Semarang: Seri Pustaka Kunci.

Gunawan, Y. I. P. (2018). Pengaruh motivasi belajar terhadap keaktifan siswa dalam mewujudkan prestasi belajar siswa. Khazanah Akademia, 02(01), 74-84.

Harmini, T. (2017). Pengaruh Kesiapan Belajar Terhadap Prestasi Belajar Mahasiswa Pada Pembelajaran Kalkulus. M A T H L I N E : Jurnal Matematika Dan Pendidikan Matematika, 2(2), 145-158. https://doi.org/10.31943/mathline.v2i2.42

Hewi, L., \& Shaleh, M. (2020). Refleksi Hasil PISA (The Programme For International Student Assesment): Upaya Perbaikan
Bertumpu Pada Pendidikan Anak Usia Dini). Jurnal Golden Age, 4(01), 30-41. https://doi.org/10.29408/jga.v4i01.2018

Jumasrin. (2019). Variabel-Variabel Relasional Kesiapan Belajar Peserta Didik di Tingkat Sekolah Dasar. Shautut Tarbiyah, 25(1), 84-107.

Junianti, S. (2019). Pengaruh Motivasi Belajar Terhadap Keaktifan Belajaar Siswa Kelas XII Akutansi SMK Yasebha Pada Mata Pelajaraan Praktikum Akutansi Perusahaan Jasa, Dgang dan Manufaktur. Skripsi.

Kasiram, M. (2008). Metodologi Penelitian. Malang : Universitas Islam Negeri Malang.

Kusuma, P. Y., \& Muhsin. (2013). Pengaruh motivasi belajar, lingkungan teman sebaya, dan bahan ajar terhadap kesiapan belajar. 2(1), 18-23.

Ma'shumah, F., \& Muhsin. (2019). Pengaruh Motivasi Belajar, Disiplin Belajar, Cara Belajar Dan Interaksi Teman Sebaya Terhadap Kesiapan Belajar. Economic Education Analysis Journal, 8(1), 318332.

Meilon, B., Mariani, S., \& Semarang, U. N. (2019). Analysis of Mathematical Representation Skills Based on Student Learning Activities in Hands on Activity Assisted PBL Learning Model. Unnes Journal of Mathematics Education Research, 8(2), 213-219. http://journal.unnes.ac.id/sju/index.php/uj mer

Nai, F. A. (2017). Teori Belajar dan Pembelajaran. Sleman : Dee Publish.

Nasution, R. H., Hapidin, H., \& Fridani, L. (2020). Pengaruh Pembelajaran ICT dan Minat Belajar terhadap Kesiapan Membaca Anak Usia Dini. Jurnal Obsesi: Jurnal Pendidikan Anak Usia Dini, 4(2), 733. https://doi.org/10.31004/obsesi.v4i2.411

Pour, A. N., Herayanti, L., \& Sukroyanti, B. A. (2018). Pengaruh Model Pembelajaran Talking Stick Terhadap Keaktifan Belajar Siswa. Jurnal Penelitian Dan Pengkajian Ilmu Pendidikan, 2(1), 36-40. https://doi.org/https://doi.org/10.36312/esaintika.v2i1.111

Ratnawati, A., \& Marimin. (2014). Pengaruh Kesiapan Belajar, Minat Belajar, Motivasi Belajar, Dan Sikap Siswa Terhadap Keaktifan Belajar Siswa Jurusan Administrasi Perkantoran Pada Mata Diklat Produktif Ap Di Smk Negeri 2 Semarang. Economic Education Analysis Journal, 3(1), 77-82.

Riyanti, F., \& Rustiana, A. (2018). Pengaruh Gaya Belajar, Kesiapan Belajar Melalui Motivasi Belajar Sebagai Variabel 
Intervening Terhadap Keaktifan Belajar. Economic Education Analysis Journal, 7(3), 1083-1099. https://doi.org/10.15294/eeaj.v7i3.28341

Rozai, A. (2017). Pengaruh Minat Belajar Terhadap Aktivitas Belajar Geografi XI IPS SMAN 5 Bandar Lampung. Skripsi.

Sabatina, D. (2014). Pengaruh Aktivitas Belajar Terhadap Prestasi Belajar Di Tinjau Dari Kemampuan Komunikasi Matematika Pada Siswa Kelas VIII Semester Genap SMP Negeri 2 Banyudono Tahun Pelajaaran 2013/2014 Surakarta. Skripsi.

Safari, M. . (2003). Evaluasi Pembelajaran. Jakarta: Dapartemen Pendidikan Nasional.

Sagala, H. (2020). Pemberian Motivasi dalam Mendorong Keaktifan Belajar Siswa Pada Pembelajaran Jarak Jauh. Skripsi.

Sears, \& Zemansky. (2002). Fisika Universitas Jilid 1. Jakarta : Erlangga.

Setiawan, A., Sawitri, D., \& Suswati, E. (2019). Pengaruh Minat Dan Lingkungan Belajar Terhadap Kesiapan Belajar Didimensi Oleh Motivasi Belajar. Jurnal Psikologi, 6(2), 94-113.

Silviani, T. R., Jailani, J., Lusyana, E., \& Rukmana, A. (2017). Upaya Meningkatkan Minat Belajar Matematika Menggunakan Inquiry Based Learning Setting Group Investigation. Kreano, Jurnal Matematika Kreatif-Inovatif, 8(2), 150-161.

https://doi.org/10.15294/kreano.v8i2.8404

Slameto. (2010). Belajar dan Faktor-Faktor yang Mempengaruhi. Jakarta: Rineka Cipta.

Sujanem, R. (2012). Pengembangan Modul Fisika Kontekstual Interaktif Berbasis Web Untuk Meningkatkan Pemahaman Konsep Dan Hasil Belajar Fisika Siswa SMA Di Singaraja. Jurnal Nasional Pendidikan Teknik Informatika (JANAPATI), 1(2), 103-117.

Suwartini, S. (2017). Pendidikan Karakter dan Pembangunan Sumber Daya Manusia Keberlanjutan. Jurnal Pendidikan, 4(1), 220-234.

https://media.neliti.com/media/publication s/259090-pendidikan-karakter-danpembangunan-sumb-e0cf1b5a.pdf

Tafonao, T. (2018). Peranan Media Pembelajaran Dalam Meningkatkan Minat Belajar Mahasiswa. Jurnal Komunikasi Pendidikan, 2(2), 103-114. https://doi.org/10.32585/jkp.v2i2.113

Uno, H. B. (2013). Teori Motivasi dan Pengukurannya. Jakarta: Bumi Aksara.

Usman, U. (2011). Menjadi Guru Profesional. Bandung: PT Remaja Rosdakarya.
Yanida, A. F., \& Pramusinto, H. (2014). Pengaruh Motivasi Belajar, Disiplin Belajar Dan Media Pembelajaran Terhadap Kesiapan Belajar Siswa Kelas X Administrasi Perkantoran Pada Mata Diklat Mengelola Peralatan Kantor Di Smk $\mathrm{Nu} 01$ Kendal. Economic Education Analysis Journal, 3(3), 516-522. 